\title{
DEMYTHOLOGIZING HISTORY: JEANETTE WINTERSON'S FICTIONS AND HIS/TORIES
}

\author{
MINE ÖZYURT KILIÇ \\ Bilkent University (Turkey)
}

\begin{abstract}
"All the books speak to each other. They are only separate books because that's how they had to be written. I see them really as one long continuous piece of work. I've said that the seven books make a cycle or a series, and I believe that they do from Oranges to The PowerBook. And they interact and themes do occur and return, disappear, come back amplified or modified, changed in some way, because it's been my journey, it's the journey of my imagination, it's the journey of my soul in those books. So continually they must address one another» ${ }^{1}$.
\end{abstract}

Winterson's novels continually address one another. Just as she states in the interview, starting with Oranges Are Not The Only Fruit ${ }^{2}$ we find themes 'occurring, returning, coming back amplified or modified' in her fiction. Among the themes that recur, an intense preoccupation with history is central. Yet none of her novels can be classified as historical in the traditional sense. In her own words, Winterson uses the past as an «invented country»; she «land[s] on some moment of history and re-discovers it». Theoretically speaking, she writes "historiographic metaficton" that blurs the line between fiction and history. Thus, her novels problematise the validity of history, as well as the validity of the traditional view that the historical and fictional are separate ${ }^{3}$. With the theory of historiography that Hayden White offered in the 1970's, the separation of the once distinct realms of factual and fictional started to be questioned. The objectivity of historical knowledge seemed problematic. Realising that it was not the facts but the historian that speaks for the audience, White thought that the writing of history was then quite similar to the poetic process; thus he concludes that since historians are also preoccupied with the act of storytelling and with finding an appropriate narrative technique for

1. ReYnolds, Margaret and Jonathan NoAkes: Jeanette Winterson: The Essential Guide, London, Vintage, 2003, p. 25.

2. Winterson, Jeanette: Oranges Are Not The Only Fruit, London, Vintage, 2001.

3. Hutcheon, Linda: A Poetics of Postmodernism, New York, Routledge, 1988, p. 113

Feminismo/s, 4, diciembre 2004, pp. 127-134 
ordering the events, history is "the literature of fact»" This way of thinking puts an end to the traditional categorisation of history and fiction.

Winterson's novels (among many other postmodernist novels) can be seen as the embodiments of such views. As one major source of inspiration for Winterson, Angela Carter says for herself, Winterson's fiction offers the reader "an argument stated in fictional terms $»^{5}$. In this sense, Winterson puts the postmodernist view of history into practice. Her views regarding history are like threads to her whole narrative adventure. Thus, what she says about history outside the fictional realm can be very enlightening in helping us understand how and why she resorts to history in her fiction. In the same interview quoted above, she explains her notion of the past and says that the past should be a place to re-invent:

«... because the past is not a place that we know. We weren't there. And no matter what records are given to us, what objects, what stories, what histories, we don't know, because we weren't present. So to get at the past fiction is as likely a way of interpreting it as any. And I do think the history is a collection of found objects washed up through time, and that some of them we do hook out, and others we ignore. And as the pattern changes, the meaning changes. We are continually understanding our past in a different way because we are continually reinterpreting it and fiction does that very well. But you can only do it well if you let some freedom in your imagination. You can't do it well if you're trying to lock yourself slavishly into your notion of the past- which will not be true anyway. Or if you're making the past into the present, but in a silly wig and a different costume» ${ }^{6}$.

Winterson 'lets her imagination free' and she never becomes the slave of the past narratives given to her. The Past in her fiction is always presented as something to invent, it is never a "silly wig» that is designed to cover up the real and to strike appearances for the slipshod.

The "talismanic» title she gives to the first novel of her cycle is integral to this innovative and pluralist attitude towards history: "Oranges are 'by no means' the Only Fruit». The novel unfolds a personal history defying the accepted norms, which find diversity thrilling in its reductionist pose and thus equal fruit with oranges only. And it starts with the "Genesis» of Jeanette who falls in love with a girl, that is, who finds out that there are roads not taken; she takes one, and that makes all the difference: She suffers the exorcism and isolation. She is nullified, so is her story because she deviates from the normal. Therefore her story will not be recorded by the mainstream culture. History, simply, will not recognise her experience of falling in love with a girl as a fact. Winterson's critique of this traditional notion of history is embedded within Jeanette's life story that gloves the tale of Parcival as an emblem of loyalty to one's own values at the cost of everything:

4. WhITE, Hayden: "The Fictions of Factual Representation», in Angus Fletcher (ed.): The Literature of Fact, New York, Columbia UP, 1976, p. 21.

5. Haffenden, John: Novelists in Interview, London, Methuen, 1985, p. 76.

6. Reynolds, Margaret and Jonathan Noakes: Op. cit., p. 22. 
"People like to separate storytelling which is not fact from history which is fact. They do this so that they know what to believe and what not to believe. This is very curious. How is it that no one will believe that the whale swallowed Jonah every day Jonah is swallowing the whale? I can see them now, stuffing down the fishiest of fish tales, and why? Because it is history. Knowing what to believe had its advantages. It built an empire and kept people where they belonged, in the bright realm of the wallet. Very often history is a means of denying the past. Denying the past is to refuse to recognise its integrity. To fit it, force it, function it, to suck out the spirit until it looks the way it should. We are all historians in our small way» ${ }^{7}$.

When later Jeanette says "History is St George», she actually summarises the way she sees the History with capital H; she senses that the sum total of History is also made up of stories of the great church fathers, the great patriarchs. To question the validity of this history, Winterson uses the titles from the Old Testament for the chapter titles of Jeanette's autobiography: Genesis, Exodus, Leviticus, Numbers, Deuteronomy, Joshua, Judges, Ruth; and gives parallel yet secular stories of Jeanette's own Testament enveloped under these titles. The re-definition that Winterson offers with the use of this technique subverts the notion of the "sacred past» by placing a "profane content» into this already-known frame. To use a Biblical term, Winterson puts "new wine into old bottles", to break the bottles: "the wine runneth out, and the bottles perish ${ }^{8}$. This indicates that the new spiritual order requires new practices; metaphorically the content and form of the material are incongruous; and in this incongruity lies the potential deconstruction which paves the way for reconstruction.

In that sense, Winterson offers a postmodernist reworking of the Old Testament and through this re-working, it is implied that Jeanette, the protagonist "cannot find her place in society, and acknowledges the fundamentally unstable condition of the world ${ }^{9}$, and is ultimately forced to find a way of existence by an act of redefining and rewriting. She knows that her efforts in creating a life of her own, her genesis and her exodus will not be recorded. When she comes to the understanding that "St George is history", she then realises that it merely ignores and mutes the distinct experiences, it only exorcises, it just discards. No wonder, her reflections upon this notion of history is not rewarding at all: "When I look at a history book and think of the imaginative effort it has taken to squeeze this oozing world between two boards and typeset, I am astonished $»^{10}$. It is diminishing, yet there is still a way to hear the oozing world for Jeanette.

7. Winterson, Jeanette: Oranges..., op. cit., pp. 91-92.

8. Matthew 9:16-17.

9. GADE, Bente: "Multiple Selves and Grafted Agents: A Postmodernist Reading of Sexing the Cherry", in Bengstson et.el. (ed.): Sponsored by Demons: The Art of Jeanette Winterson, Odense, Scholar's Press, 1999, p. 31.

10. Winterson, Jeanette: Oranges..., op. cit., p. 93. 
The cure for this reduction and distortion is «self-service». What does it mean? OK! Rather than being a subject, a prey to the "Holy Service» performed by the patriarchal authorities, to protect our body against the harms of «too much refined food" we should have our own food: "If you always eat out you can never be sure what's going in, and received information is nobody's exercise. Rotten and rotting. Here is some advice. If you want to keep your own teeth make your own sandwiches ${ }^{11}$. So, Oranges not only problematises the validity of patriarchal history, but also offers a solution: Record your own story, and do not rely on the History, served as fast food. As such, the "story" of Jeanette becomes a story of universal proportions in which the heroine struggles against the oppression of those obsessed with putting limits on passion, desire and the expression of love $e^{12}$. In this respect, it can be suggested that the historical fragments function as universalising agents for the fictional, and vice versa. (The fictional bit makes the historical sound less factual!).

Winterson's fiction elaborates on the concept of history, the notions of past and time also by juxtaposing the fictional and historical characters within the same space. Historical figures from different fields, namely political, military, religious and literary heroes exist side by side with the fictional characters. They are different, yet they share something in common: They are interestingly all male. These heroes, Napoléon, Cromwell, the Puritans and even the beheaded King Charles I are in fact powerful so much so that history does not mute them, knowledge does not refute their existence, (as it does to Cassandra in the myth/ poster) they are recognised everywhere and remembered at every pore. Nicholas Jordan in Sexing the Cherry who serves as her mouthpiece articulates Winterson's response to this male-centred notion of heroism. Upon reading selections from his favourite book, The Boys' Book of Heroes, a collection of the short biographies of men like William the Conqueror, Francis Drake, Lord Nelson and Christopher Colombus, Nicholas Jordan infers that:

"If you are a hero you can be an idiot, behave badly, ruin your personal life, have any number of mistresses and talk about yourself all the time, and nobody minds. Heroes are immune. They have wide shoulders and plenty of hair and wherever they go a crowd gathers. Mostly they enjoy the company of other men, although attractive women are part of their reward $»^{13}$.

The ecologist girl's response is similar to that of Nicholas Jordan, whose plan is to do away first with the World Bank and then with the Pentagon. In an ideal world that achieves to beat the pollution, men should also act differently for her: "I don't hate men", she says, "I just wish they'd try harder. They all want to be heroes and all we want is for them to stay home and help with the housework and kids. That's not the heroism they enjoy» ${ }^{14}$. A reinforcement

11. Ibid., p. 93.

12. Kitzman, Andreas: "Untouchable Spaces: The Literary Inventions of Jeanette Winterson", in Proceedings of the Seventeenth All-Turkey English Literature Conference, Sivas, 10-12 April 1996, Sivas, Cumhuriyet University Press, 1996, p. 63.

13. Winterson, Jeanette: Sexing the Cherry, New York, Vintage, 1991, p. 113.

14. Ibid., p. 145. 
of the critique she makes comes from another figure in the novel, Fortunata, one of the twelve dancing princesses who walks a different road (like Jeanette of Oranges, like the Dog-woman of Sexing). Fortunata is said to know about "the heroes and the home-makers, the great division that made life possible» ${ }^{15}$. Fortunata does not reject this division; instead she simply hopes to take on the freedoms of the other side, but then the question comes: "What if she travelled the world and the seven seas like a hero? Would she find something different or the old things in different disguises ${ }^{16}$.

The heroes from History co-habit with the fictional characters and they dwell both in the present and the past. And I think in placing these figures into the fictional space of her novels, and bringing them forth to the present, Winterson shakes the pedestals that these male heroes are put on from the roots. Meanwhile, through the simultaneous existence of both the fictional and the historical, the separation of the literary and the historical is challenged ${ }^{17}$. What Hutcheon says of such machinations is applicable to Winterson's fiction: "Postmodernist fiction suggests that to re-write or to re-present the past in fiction and in history is, in both cases, to open it up to the present, to prevent it from being conclusive and teleological $\aleph^{18}$.

In Winterson, the historical figures then cease to be as omnipotent and omniscient as they used to be in the social and cultural fictions governing the everyday life. Her novels give the lies away since they reveal that the heroes do not exist in the middle of nowhere. They are not beings apart indeed. The truth is, there are some other figures around who are equally real such as Napoléon's neck-wringer Henri who always wanted to be a drummer, who had dreams of being like Napoléon, and another equally real figure is Patrick, "the de-frocked priest with the eagle eye ${ }^{19}$. Napoléon, General Hoche and Admiral Nelson of The Passion, and Cromwell, Charles I and the Puritans of Sexing the Cherry are all reduced to be mere subjects to their author's whims; their existence is just as precarious as the other characters, representatives of the common people, due to the breaks in narratives, intervening voices, different narrators and questions regarding the validity of fiction. How long do you think the myth of Napoléon can stand among the din of "I am telling you stories? Trust me.» How long can the serious and unyielding image of Cromwell and the Puritans sustain with the deconstructive notion of history pervading the novel:

"There was no history that would not be rewritten and the earliest days were already too far away to see. What would history make of tonight? Tonight is clear and cold.... The stars show [the night] how to hang in space supported by nothing at all. Without medals or certificates or territories she owns, she can burn as they do, travelling through time until time has no meaning any more ${ }^{20}$.

15. Ibid, p. 150.

16. Ibid.

17. Hutcheon, Linda: Op. cit., p. 104.

18. Ibid., p. 110.

19. Winterson, Jeanette: Passion, London, Bloomsbury, 1991, p. 24.

20. Winterson, Jeanette: Sexing..., op. cit., p. 153. 
Similar to Jordan's philosophising in Sexing, Henri's diary keeping during the Napelonic wars in Passion stands as an alternative form of history-writing to the military history supported by medals, certificates and territories. What the history books write is in Henri's hands turned into stories. Even this is problematised. This is emphasised by his friend Domino whose criticism of the way diaries are kept also questions the validity of the general trend in history-writing: "The way you see it now is no more real than the way you'll see it then». Henri cannot agree with him in drawing that then one should not write at all; however, he also thinks that he knows how old men blurred and lied making the past always the best because it was gone, thus questions the indisputable authority of the "old historian»:

"Look at you' said Domino, 'a young man brought up by a priest and a pious mother. A young man who can't pick up a musket to shoot a rabbit. What makes you think you can see anything clearly? What gives you the right to make a notebook and shake it at me in thirty years, if we're still alive, and say you've got the truth? ${ }^{21}$.

They settle the trouble when Henri tells Domino that what he cares about is not the facts but how he feels; he argues that how he feels will certainly change; so, he jots down his feelings since he wants to remember them. Thus, like Jordan, Henri deals with «the marginal (hi)stories that would not otherwise be told", and goes on with his diary-keeping ${ }^{22}$. Domino raises the issue once again when he tells Henri about the fortune-tellers he knows. There, he states the underlying notion of history in Winterson's fiction and addresses Henri whom is seen as the audience: "I tell you, Henri that every moment you steal from the present is a moment you have lost forever. There's only now ${ }^{23}$. Then when Henri tells stories about the camp at Boulogne, he is aware of the distortion or revision that he, as a historian, makes: "I embroidered and invented and even lied. Why not? It made them happy. I didn't talk about the men who have married mermaids $»^{24}$. The marriage of the soldiers to the mermaids refers to the disaster at sea, namely hundreds of them sinking into the depths of the sea in the battle. Both Henri and Domino articulate the underlying notion of history then: There is no single truth, the story told by a single person is not the absolute or the ultimate; in a sense, "History» is a tale told by an idiot, full of sound and fury, signifying nothing! Domino's commentary makes us realise that there is no one truth about history, only a series of versions, and that the past is available only in its various texts.

21. Winterson, Jeanette: Passion..., op. cit., p. 47

22. Bengston, Helene: "The Vast Unmappable Cities of the Interior: Place and Passion in The Passion", in Sponsored by Demons: The Art of Jeanette Winterson, Odense, Scholar's Press, 1999, p. 23.

23. Winterson, Jeanette: Passion..., op. cit., p. 48.

24. Ibid., p. 50. 
One technique Winterson uses in problematising history, as we have seen, is the juxtaposition of the characters -historical and fictional. Parallel events picked out from both the past and the present also help Winterson play with the ossified, monumental history, and destroy and the hard-boiled facts of that history. For instance, The Great Fire of London of 1666 and Nicholas Jordan's and the chemist girl's wish to burn down the polluting factory in modern London occur simultaneously. Two Londons, London of the past and the present exist side by side. The plague of 1665 is put against the pollution of the modern world. Jordan who belongs to the realm of the past events, an alter-ego to Nicholas Jordan, concludes that: "The future and the present and the past exist only in our minds, and from a distance the borders of each shrink and fade like the borders of hostile countries seen from a floating city in the sky... Empty space and points of light. ${ }^{25}$

So, important events like wars, executions, fires, victories, discoveries, that is the deeds of historical figures are seen as points of light in an empty space just like the other deeds of other characters. This is, I will call, a "demythologising notion of history» that levels down all the differences between male and female, now and then, Roundheads and the Royalists, the French and the English, the Emperor and the neck-wringer, the priest and a PeepingTom, a Fairy and a little girl, the Dog-woman and the ecologist. This sort of de-mythologising attitude also hightens the thematic effect that Winterson intends to create. The ultimate result of such plays is the universal dimension that the fictional world gains. For instance, Henri ends his life in a madhouse in an island, like Napoléon's exile in St Helene; Ali, the narrator of The PowerBook, feels like the tragic lovers of literary history Lancelot and Guinevere, Romeo and Juliet, Abelard and Heloise, Tristan and Isolde, frustrated desire of George Mallory who failed to reach the summit of Everest and the frustrated desire of Ali as a lover. These events are all put into the same bowl.

By putting such different figures from different periods of time together in a single thematic network, Winterson seems to deny the prevalent notion of time that separates these people from one another with the border of temporality. She makes different figures from various walks of life, from different historical periods come together in the same line of thought, in the same sort of mood; in a sense, it is not "when» but "what» that counts for these figures. The PowerBook, the last book of her first cycle has the motto. Ali, the narrator wonders if St Augustine might be right as he questions the validity of the prevalent notion of time:

"St Augustine had said that the universe was not created in time but with time. This is true of the stories. They have no date. We can say when they were written or told, but they have no date. Stories are simultaneous with time. Ali the storyteller is no longer sure when things happen ${ }^{26}$.

25. Winterson, Jeanette: Sexing..., op. cit., p. 167.

26. Winterson, Jeanette: The PowerBook, London, Jonathan Cape, 2000, p. 216. 
The juxtaposition she uses also makes the reader hear the echo of old Anglo-Saxon gleeman Deor who tries to comfort himself by remembering other sorrows of the world. To console himself of each sorrow, he says "That passed away; so may this ${ }^{27}$. Winterson seems to recall the sorrows of others to measure the present sorrows against. Of course the pessimism pervading Deor's complaint is turned into hope in Winterson. Her fiction restores the lost hope and optimism.

In conclusion, the various forms of juxtapositions Winterson employs in her fiction enables the reader to grasp a new vision; the objects are washed up and hooked out from the river of events; the raw material is cooked, processed and prepared. Hence, the conclusive and teleological history is questioned at every pore: "Of course, it may well be that spiteful Suetonius (Roman historian) was a slandermonger. Perhaps Tiberius never did hurl his enemies into space-time». This sort of philosophising results in the distortion of the monolithic, stable and monumental history; her fiction gains an aspect of plasticity enabling the reader to see the past from a fresh perspective. It is clear that Winterson employs a regenerative technique: As the reader is able to find an individual voice in the historical material, s/he perceives the feeling of presence in the past. In other words, by historicizing the individual experiences, Winterson gives power and narratibility to individual lives to make them audible, narratable, and authorial.

\section{SELECTED BIBLIOGRAPHY}

Bengston, Helene: "The Vast Unmappable Cities of the Interior: Place and Passion in The Passion", in Sponsored by Demons: The Art of Jeanette Winterson, Odense, Scholar's Press, 1999.

GADE, Bente: «Multiple Selves and Grafted Agents: A Postmodernist Reading of Sexing the Cherry", in Bengstson et al. (eds.): Sponsored by Demons: The Art of Jeanette Winterson, Odense, Scholar's Press, 1999.

Haffenden, John: Novelists in Interview, London, Methuen, 1985.

Hutcheon, Linda: A Poetics of Postmodernism: History, Theory, Fiction, New York, Routledge, 1988.

KITZMANN, Andreas: «Untouchable Spaces: The Literary Inventions of Jeanette Winterson», in Proceedings of the Seventeenth All-Turkey English Literature Conference, Sivas, 10-12 April 1996, Sivas, Cumhuriyet University Press, 1996.

ReYNOLDS, Margaret and Jonathan NOAKES: "Interview with Jeanette Winterson», in Jeanette Winterson: The Essential Guide, London, Vintage, 2003.

URGAN, Mina: Ingiliz Edebiyatı Tarihi, Vol. I., Istanbul, Altın Kitaplar, 1986.

White, Hayden: "The Fictions of Factual Representation", in Angus Fletcher (ed.): The Literature of Fact, New York, Columbia UP, 1976.

Winterson, Jeanette: Oranges Are Not the Only Fruit, London, Vintage, 2001.

- The Passion, London, Bloomsbury Publishing Ltd, 1991.

- Sexing the Cherry, New York, Vintage, 1991.

- The PowerBook, London, Jonathan Cape, 2000.

27. URGan, Mina: Ingiliz Edebiyatı Tarihi, Vol. I, Istanbul, Altın Kitaplar, 1986, p. 20. 